\title{
The brachyopoid Hadrokkosaurus bradyi from the early Middle Triassic of Arizona, and a phylogenetic analysis of lower jaw characters in temnospondyl amphibians
}

\author{
Marcello Ruta and John R. Bolt \\ Acta Palaeontologica Polonica 53 (4), 2008: 579-592 doi:http://dx.doi.org/10.4202/app.2008.0403
}

The holotype of the brachyopoid temnospondyl Hadrokkosaurus bradyi, represented by a right lower jaw ramus, is re-examined based upon new data and revision of various morphological features. Additional fragmentary jaw material referred to this species is briefly described. Prominent features are a large postsymphyseal foramen that is anteriorly open, and prearticular and surangular buttresses for support of the articular. Brachyopoid characters include a long and robust postglenoid area formed by surangular and prearticular, anterior and posterior keels on at least some marginal dentary teeth, and subtriangular outline of the adductor fossa in dorsal view. Five features of the holotype ramus, long thought to be at odds with its brachyopoid or temnospondyl nature, are critically re-evaluated. A phylogenetic analysis of lower jaw characters in temnospondyls retrieves most of the clades found in more comprehensive data sets, but the statistical node support is low. Brachyopoids are monophyletic, with Hadrokkosaurus emerging as their most basal taxon.

Key words: Temnospondyli, Brachyopidae, Chigutisauridae, lower jaw, phylogeny, characters, evolution.

Marcello Ruta [m.ruta@bristol.ac.uk], Department of Earth Sciences, University of Bristol, Wills Memorial Building, Queen's Road, Bristol BS8 1RJ, UK; John R. Bolt [jbolt@fieldmuseum.org], Department of Geology, The Field Museum of Natural History, 1400 South Lake Shore Drive, Chicago, IL 60605-2496, USA. 
PaF F Full text $(637.1 \mathrm{kB})$ ।

POFif Supplementary file $(87.1 \mathrm{kB})$ 